\title{
Extraction of Gallium(III) with a New Azo Dye in The Presence or Absence of Xylometazoline Hydrochloride
}

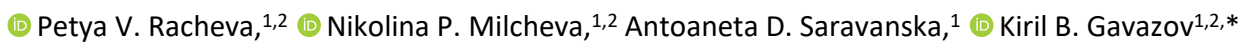

\author{
1 Department of Chemical Sciences, Medical University of Plovdiv, 120 Buxton Brothers St., Plovdiv 4004, Bulgaria \\ 2 Research Institute at the Medical University of Plovdiv, 15A Vasil Aprilov Bld., Plovdiv, Bulgaria \\ * Corresponding author's e-mail address: kgavazov@abv.bg \\ RECEIVED: December 11, 2020 * REVISED: February 10, 2021 * ACCEPTED: February 12, 2021
}

\begin{abstract}
Complex formation between $\mathrm{Ga}$ (III) and 6-hexyl-4-(2-thiazolylazo)resorcinol (HTAR, $\mathrm{H}_{2} \mathrm{~L}$ ) was studied in a water-chloroform medium, in the presence or absence of xylometazoline hydrochloride (XMH). Optimum conditions for the extraction of $\mathrm{Ga}(\mathrm{III})$ were found. In the presence of $\mathrm{XMH}$, the extracted ion-associate has the formula $\left(\mathrm{XMH}^{+}\right)\left[\mathrm{Ga} \mathrm{G}^{\mathrm{II}} \mathrm{L}\right]$, where HTAR is in its deprotonated form $\mathrm{L}^{2-}$. Some key extractionspectrophotometric characteristics were determined: absorption maximum $(521 \mathrm{~nm})$, apparent molar absorptivity $\left(5.8 \times 10^{4} \mathrm{dm}^{3} \mathrm{~mol}^{-1} \mathrm{~cm}^{-1}\right)$, limit of detection $\left(18 \mathrm{n} \mathrm{cm}^{-3}\right)$, limit of quantitation $\left(60 \mathrm{ng} \mathrm{cm}^{-3}\right)$, extraction constant ( $\left.\log K=4.44\right)$, distribution ratio $(\log D=2.2)$ and fraction extracted $(99.3 \%)$. In the absence of XMH, the extracted chelate contains one deprotonated and one monoprotonated HTAR: [Ga"'(HL-)( $\left.\left(\mathrm{L}^{2}\right)\right]$. It has an absorption maximum at $523 \mathrm{~nm}$ and a shoulder at 580-590 nm. The $\mathrm{p} K_{\mathrm{a}}$ of $\mathrm{HTAR}\left(\mathrm{H}_{2} \mathrm{~L} \rightleftarrows \mathrm{H}^{+}+\mathrm{HL}^{-}\right.$equilibrium) was calculated (5.4) and the effect of foreign ions was studied.
\end{abstract}

Keywords: gallium, 6-hexyl-4-(2-thiazolylazo)resorcinol, xylometazoline hydrochloride, liquid-liquid extraction, ion-association, spectrophotometry.

\section{INTRODUCTION}

G ALLIUM is a dispersed rare element in the Earth's crust with an average content of about 17 ppm. It belongs to the p-block of the periodic table and is classified as a post-transition metal. Some peculiarities of gallium's geochemical behavior are the reason for the lack of its own minerals in economically significant quantities. ${ }^{[1]}$ This, along with gallium high tech and military applications, makes it a strategic metal. ${ }^{[2-4]}$ Currently, gallium is difficult to be replaced by other materials ${ }^{[5]}$ in most of its uses in microelectronics, optics, renewable energetics, data storage, low-freezing-point alloys, plutonium alloys and medicine. Therefore, the interest in its extraction, separation, recycling and determination is great. ${ }^{[4,6-12]}$

Gallium(III) forms intensely colored chelate species with azo dyes, such as 4-(2-pyridylazo)resorcinol (PAR) and 4-(2thiazolylazo)resorcinol (TAR). ${ }^{[13-18]}$ Cationic ion-association reagents have been used in our laboratory to improve the hydrophobicity and extraction characteristics of such chelates: tetrazolium salts, ${ }^{[19,20]}$ nitron $^{[21]}$ and xylometazoline hydrochloride $(\mathrm{XMH}){ }^{[22]}$ Extraction systems containing both Ga(III) and 6-hexyl-4-(2-thiazolylazo)resorcinol (HTAR) have not been studied so far. The aim of this paper is to investigate the complex formation between $\mathrm{Ga}$ (III) and HTAR in water-chloroform medium in the presence or absence of XMH. The azo dye HTAR is both commercially available and poorly studied. It is part of a collection of rare and unique chemicals and can be considered a good candidate for complexation with gallium ions due to the presence of a favorable combination of donor atoms. In a previous work on vanadium(V) liquid-liquid extraction, we reported its advantages over well-known azo dyes in terms of hydrophobicity and color-forming properties. ${ }^{[23]}$ The other reagent, $\mathrm{XMH}$, has been used in medicine and analytical chemistry. Its cation $\left(\mathrm{XMH}^{+}\right)$has a dispersed positive charge ${ }^{[24]}$ and tends to form ion-pairs with various complex anions. ${ }^{[22,23,25-27]}$ 


\section{MATERIALS AND METHODS}

\section{Reagents and Apparatus}

A stock $\mathrm{Ga}$ (III) solution was prepared by dissolving $0.1346 \mathrm{~g}$ of $\mathrm{Ga}_{2} \mathrm{O}_{3}$ (Koch-Light Laboratories Ltd., 99,99 \%) in a hot conc. $\mathrm{HCl}$ solution $\left(20 \mathrm{~cm}^{3}\right)$. After cooling, the obtained solution was collected into a $100-\mathrm{cm}^{3}$ calibrated flask and diluted to the mark with $6.5 \mathrm{~mol} \mathrm{dm}^{-3} \mathrm{HCl}^{[19]}$ The working solutions $\left(1 \times 10^{-4} \mathrm{~mol} \mathrm{dm}^{-3}\right)$ were prepared by appropriate dilution of the stock solution with water. The reagents, $\mathrm{XMH}$ (purity $\geq 99 \%$ ) and HTAR, were purchased from Merck. Aqueous solutions of XMH $\left(2 \times 10^{-2} \mathrm{~mol} \mathrm{dm}^{-3}\right)$ and HTAR $\left(2 \times 10^{-3} \mathrm{~mol} \mathrm{dm}^{-3}\right)$ were used. To increase the solubility of HTAR in water, its solution was prepared by the addition of $\mathrm{KOH} .{ }^{[23]}$ The $\mathrm{pH}$ values of the aqueous phase were adjusted by using ammonium acetate buffer prepared by mixing $2.0 \mathrm{~mol} \mathrm{dm}^{-3}$ solutions of acetic acid and ammonia. The $\mathrm{pH}$ was monitored by a WTW InoLab $720 \mathrm{pH}$-meter (Germany). Absorbance was measured using a Ultrospec3300 pro spectrophotometer (UK), equipped with 10$\mathrm{mm}$ path-length cells. Distilled water was used in all experiments. The chloroform was purified by distillation and used repeatedly.

\section{General Procedure for One-Factor-at-a- Time Optimization}

Solutions of $\mathrm{Ga}(\mathrm{III})$, HTAR, buffer and XMH were pipetted into a separatory funnel. Water was added to the total volume of $10 \mathrm{~cm}^{3}$. Then chloroform $\left(10 \mathrm{~cm}^{3}\right)$ was buretted and the mixture was shaken for extraction. After a short wait for phase separation, a portion of the organic layer was transferred through a filter paper into the spectrophotometer cell. The absorbance was measured against chloroform or a blank prepared at the same time.

\section{Procedure for Studying the Effect of Foreign lons}

The effect of foreign ions was studied under optimal conditions for $\mathrm{Ga}(\mathrm{III})$ extraction. For this purpose, a certain

Table 1. Optimization of the Ga(III) - HTAR - XMH - water chloroform system. ${ }^{\text {(a) }}$

\begin{tabular}{ccc}
\hline Parameter & $\begin{array}{c}\text { Optimization } \\
\text { range }\end{array}$ & $\begin{array}{c}\text { Optimal } \\
\text { value }\end{array}$ \\
\hline Wavelength, $\mathrm{nm}$ & Visible range & 521 \\
pH & $3.67-9.15$ & 5.0 \\
Concentration of HTAR, mol dm & $(0.14-2.0) \times 10^{-4}$ & $1.4 \times 10^{-4}$ \\
Concentration of XMH, mol dm ${ }^{-3}$ & $(0-2.0) \times 10^{-3}$ & $1.0 \times 10^{-3}$ \\
Extraction time, seconds & $15-240$ & 180 \\
\hline
\end{tabular}

(a) The optimization was performed at room temperature $\left(22^{\circ} \mathrm{C}\right)$, equal volumes of the two phases $\left(10 \mathrm{~cm}^{3}\right)$ and $c_{G a}=1.0 \times 10^{-5}$. amount of the foreign ion solution was added into a separatory funnel containing $0.5 \mathrm{~cm}^{3}$ of $2 \times 10^{-4} \mathrm{~mol} \mathrm{dm}^{-3} \mathrm{Ga}$ (III) solution. Then, $0.7 \mathrm{~mL}$ of $2 \times 10^{-3} \mathrm{~mol} \mathrm{dm}^{-3}$ HTAR solution, $3 \mathrm{~cm}^{3}$ buffer ( $\mathrm{pH} 5.0$ ) and $0.5 \mathrm{~mL}$ of $2 \times 10^{-2} \mathrm{~mol} \mathrm{dm}^{-3} \mathrm{XMH}$ solution were added. The resulting solution was diluted with water to $10 \mathrm{~cm}^{3}$ and shaken for $3 \mathrm{~min}$ with chloroform $\left(10 \mathrm{~cm}^{3}\right)$. After a short wait for phase separation, a portion of the organic layer was transferred through a filter paper into the spectrophotometer cell. The absorbance was measured at $521 \mathrm{~nm}$ against chloroform or a sample prepared simultaneously in the absence of a foreign ion.

\section{Determination of the Distribution Ratio and Fraction Extracted}

The distribution ratio $(D)$ was found from the equation $D=$ $A_{1} /\left(A_{3}-A_{1}\right)$, where $A_{1}$ is the absorbance measured after a single extraction (under the optimal conditions, Table 1 ) and $A_{3}$ is the absorbance after a triple extraction under the same conditions. ${ }^{[28]}$ The total volume in both cases (single and triple extraction) was $25 \mathrm{~cm}^{3}$. The fraction extracted $(E)$ was calculated from the equation $E / \%=100 \times D /(D+1)$.

\section{RESULTS AND DISCUSSION}

\section{Absorption Spectra}

Spectra of chloroform extracts of Ga(III)-HTAR complexes in the absence $(1)$ or presence $(2,3)$ of $\mathrm{XMH}$ are shown in Figure 1 . The spectrum 1 is characterized by a maximum at $523 \mathrm{~nm}$ and a shoulder at about 580-590 nm. The maximum at the optimum conditions in the presence of

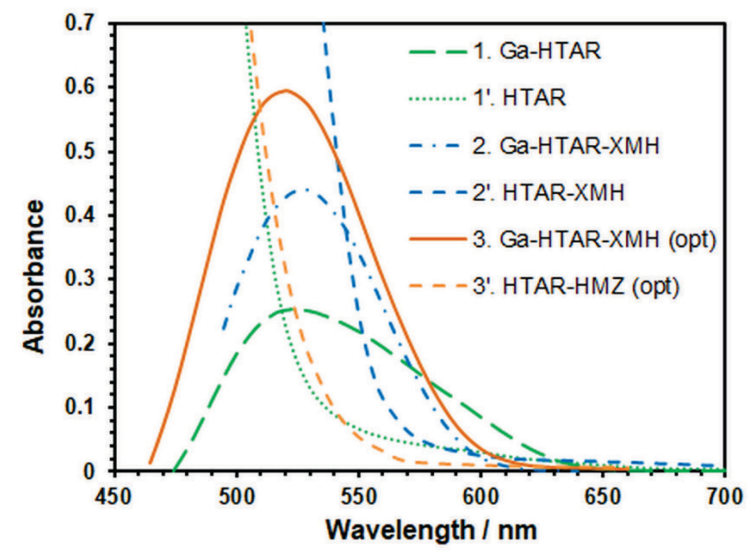

Figure 1. Absorption spectra of complexes against blanks (13; $c_{\mathrm{Ga}}=1 \times 10^{-5} \mathrm{~mol} \mathrm{dm}^{-3}, t_{\mathrm{ex}}=3 \mathrm{~min}$ ) and corresponding blanks against chloroform $\left(1^{\prime}-3^{\prime}\right)$.

$\left(1,1^{\prime}\right) C_{\text {HTAR }}=2 \times 10^{-4} \mathrm{~mol} \mathrm{dm}^{-3}, \mathrm{pH}=6.4 ;\left(2,2^{\prime}\right) C_{\text {HTAR }}=$ $2 \times 10^{-4} \mathrm{~mol} \mathrm{dm}^{-3}, c_{\times \mathrm{MH}}=2 \times 10^{-3} \mathrm{~mol} \mathrm{dm}^{-3}, \mathrm{pH}=7.9$; $\left(3,3^{\prime}\right) C_{\text {HTAR }}=1.4 \times 10^{-4} \mathrm{~mol} \mathrm{dm}^{-3}, c_{X M H}=1 \times 10^{-3} \mathrm{~mol} \mathrm{dm}^{-3}$, $\mathrm{pH}=5.0$. 


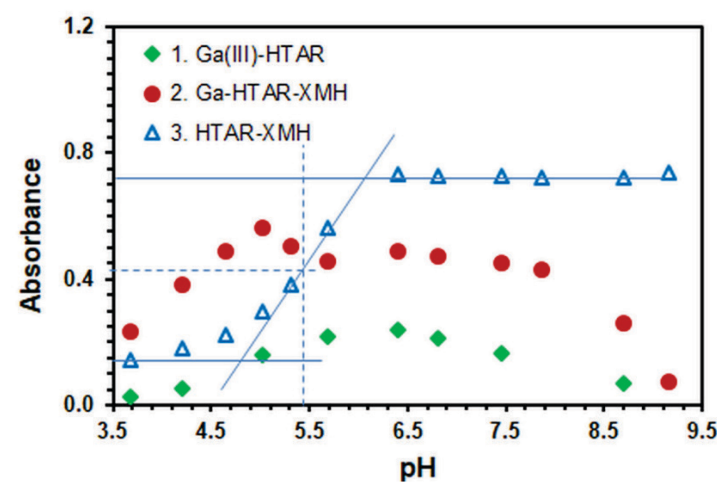

Figure 2. Effect of $\mathrm{pH}$ of the aqueous phase on the absorbance $(\lambda=523 \mathrm{~nm})$. (1) $c_{G a}=2 \times 10^{-5} \mathrm{~mol} \mathrm{dm}^{-3}$, $c_{\text {TAR }}=2 \times 10^{-4} \mathrm{~mol} \mathrm{dm}^{-3} ;(2) c_{\mathrm{Ga}}=1 \times 10^{-5} \mathrm{~mol} \mathrm{dm}^{-3}, c_{\mathrm{HTAR}}=$ $2 \times 10^{-4} \mathrm{~mol} \mathrm{dm}^{-3}, C_{X M H}=2 \times 10^{-3} \mathrm{~mol} \mathrm{dm}^{-3}$; (3) $C_{\text {HTAR }}=$ $2 \times 10^{-4} \mathrm{~mol} \mathrm{dm}^{-3}, C_{\mathrm{XMH}}=2 \times 10^{-3} \mathrm{~mol} \mathrm{dm}^{-3}$.

$\mathrm{XMH}(3)$ appears at $521 \mathrm{~nm}$ and the shoulder at 580-590 $\mathrm{nm}$ is missing. This shoulder is observed only in the absence of $\mathrm{XMH}$.

\section{Effect of pH}

The effect of $\mathrm{pH}$ is shown in Figure 2. All experiments were performed in the presence of $3 \mathrm{~cm}^{3}$ of ammonia-acetate buffer. The maximum of series 1 , obtained in the absence of $\mathrm{XMH}$, lies at $\mathrm{pH} 6.4$, and the curve is symmetrical (bellshaped). The absorbance profile in the presence of $\mathrm{XMH}$ (2) is more complex. With an increase in $\mathrm{pH}$ from 3.5 to 5.0, the absorbance increases almost linearly. The maximum $(\mathrm{pH}$ 5.04) is followed by a section ( $\mathrm{pH}$ 5.7-7.9) where the absorption remains practically constant. A sharp decrease follows at higher $\mathrm{pH}$ values, most likely due to the formation of hydrolysis products. ${ }^{[29]}$

Series 3 shows the increase in absorbance of the blank (HTAR-XMH) with increasing $\mathrm{pH}$. It allows to calculate the dissociation constant $K_{\mathrm{a}}$, which characterizes the loss of the proton of the $\mathrm{OH}$ group in the $\mathrm{p}$-position relative to the azo group (Figure 3).

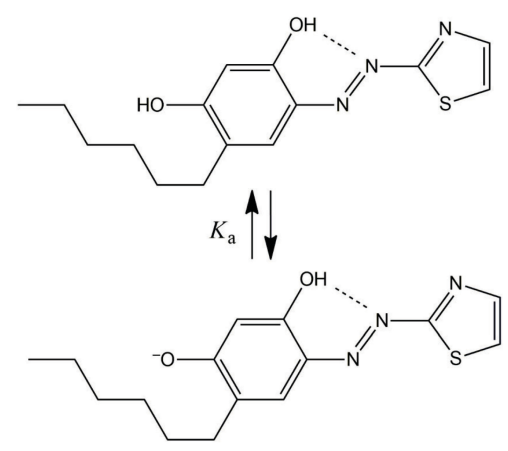

Figure 3. Equilibrium between the two forms of HTAR $\left(\mathrm{H}_{2} \mathrm{~L}\right.$ and $\mathrm{HL}^{-}$).
One can estimate from Figure 2 (series 3 ) that the $\mathrm{p} K_{\mathrm{a}}$ of HTAR is $c a$ 5.4. This $p K_{\text {a }}$ value is close to those for other reagents of the same class ${ }^{[30-33]}$ and is expected to decrease at higher XMH concentrations. ${ }^{[33]}$ At $\mathrm{pH}>5.4$, HTAR predominantly exists in its monoprotonated anionic form $\left(\mathrm{HL}^{-}\right)$, which is able to associate with $\mathrm{XMH}^{+}$to form an electroneutral, well extractable ion-pair. The formula of this ionpair is most likely $\left(\mathrm{XMH}^{+}\right)\left(\mathrm{HL}^{-}\right)$, which is in agreement with previous studies of similar compounds. ${ }^{[34,35]}$ Its absorption maximum is determined by the anionic moiety and is located at $454 \mathrm{~nm}$ (in chloroform).

\section{EFFECT OF REAGENTS' CONCENTRATION, MOLAR RATIOS, FORMULAE AND EQUATIONS}

The effect of HTAR concentration on absorbance in the absence and presence of XMH is shown in Figure 4, series 1 and 2, respectively. The effect of $c_{\mathrm{XMH}}$ at the optimum $\mathrm{pH}$ and $c_{\text {HTAR }}$ is shown in Figure 5.

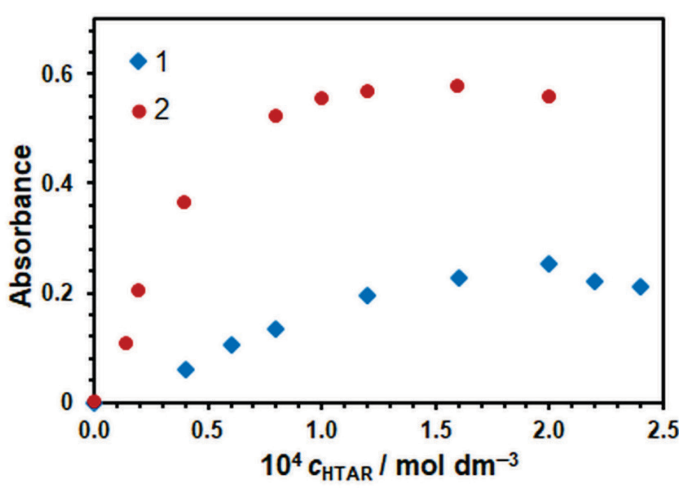

Figure 4. Effect of HTAR concentration in the absence (1) or

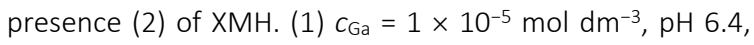
$t_{\mathrm{ex}}=3 \mathrm{~min}, \lambda=523 \mathrm{~nm}$; (2) $c_{\mathrm{Ga}}=1 \times 10^{-5} \mathrm{~mol} \mathrm{dm}^{-3}, c_{\mathrm{XMH}}=$ $2 \times 10^{-3} \mathrm{~mol} \mathrm{dm}^{-3}, \mathrm{pH} 5.0, t_{\mathrm{ex}}=3 \mathrm{~min}, \lambda=521 \mathrm{~nm}$.

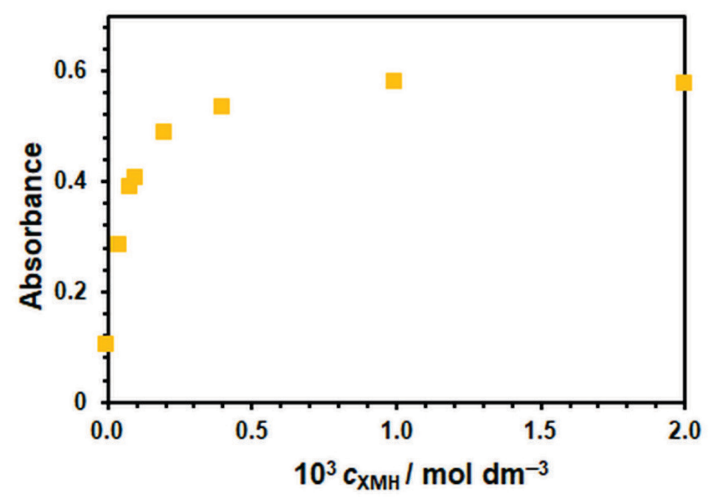

Figure 5. Effect of $\mathrm{XMH}$ concentration on the absorbance. $c_{\mathrm{Ga}}=1 \times 10^{-5} \mathrm{~mol} \mathrm{dm}^{-3}, c_{\text {HTAR }}=1.4 \times 10^{-4} \mathrm{~mol} \mathrm{dm}^{-3}, \mathrm{pH} 5.0$, $t_{\mathrm{ex}}=3 \mathrm{~min}, \lambda=521 \mathrm{~nm}$. 
The experimental data in Figure 4 were processed by two methods ${ }^{[36,37]}$ to find the HTAR-to-Ga molar ratio in the extracted species. The results (Figures 6 and 7) show that this ratio is $2: 1$ regardless of whether $\mathrm{XMH}$ is present or absent. The complex obtained in the absence of $\mathrm{XMH}$ most probably contains one deprotonated $\left(\mathrm{L}^{2-}\right)$ and one monoprotonated ligand $\left(\mathrm{HL}^{-}\right)$as shown in [Eq. (1)].

$$
2 \mathrm{H}_{2} \mathrm{~L}_{(\mathrm{aq})}+\mathrm{Ga}^{\prime \prime \prime \prime}(\mathrm{aq}) \rightleftarrows\left[\mathrm{Ga}{ }^{\prime \prime \prime}(\mathrm{HL}) \mathrm{L}^{0}{ }_{(\mathrm{org})}+3 \mathrm{H}^{+}{ }_{(\mathrm{aq})}\right.
$$

The molar XMH-to-Ga ratio in the ternary complex is $1: 1$ (Figures 6 and 7c). Hence, its composition is $n_{\mathrm{Ga}}: n_{\text {HTAR }}$ : $n_{\text {ХМн }}=1: 2: 1$. Under the optimal conditions, it is formed according to [Eq. (2)].

$$
\begin{aligned}
& \mathrm{Ga}^{\prime \prime \prime}{ }_{\text {(aq) }}+2 \mathrm{H}_{2} \mathrm{~L}_{\text {(aq) }}+\mathrm{XMH}^{+}{ }_{\text {(aq) }} \rightleftarrows \\
& (\mathrm{XMH})\left[\mathrm{Ga}^{\prime \prime \prime} \mathrm{L}_{2}\right]^{0}{ }_{(\text {org })}+4 \mathrm{H}^{+}{ }_{\text {(aq) }}
\end{aligned}
$$

The correctness of the proposed formulas and equations is confirmed by the following facts:

- The ternary complex is more intensely colored than $[\mathrm{GaL}(\mathrm{HL})]$. This is an indication that it does not contain protonated ligands.

- The shoulder in the long-wavelength part of the spectrum of the binary complex can be attributed to the presence of the ligand in two different protonation states, $\mathrm{HL}^{-}$and $\mathrm{L}^{2-}$ (as shown for transition metal complexes with azo dyes). ${ }^{[32,38]}$

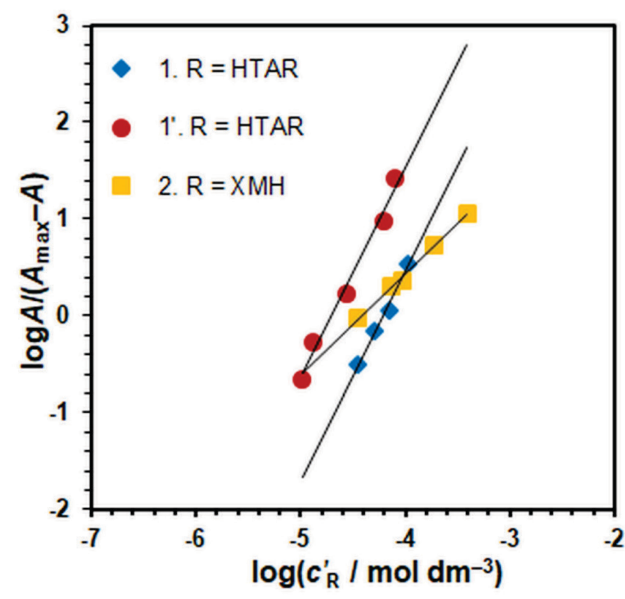

Figure 6. Determination of the HTAR-to-Ga molar ratio in the absence (1) and presence ( $\left.1^{\prime}\right)$ of $\mathrm{XMH}$ and the $\mathrm{XMH}$-toGa molar ratio (2) by the mobile equilibrium method. The experimental conditions are given in Figures 4 and 5, respectively. Straight-line equations: (1) $y=2.2 x+9.1, R^{2}=$ 0.9923; $\left(1^{\prime}\right) y=2.2 x+10.1, R^{2}=0.9860 ;(2) y=1.04 x+4.6$, $R^{2}=0.9971$

\section{Extraction Characteristics}

The conditional equilibrium constant characterizing [Eq. (2)] was calculated by the mobile equilibrium method[36] (Figure 6, straight line 2) and the Holme-Langhmyir
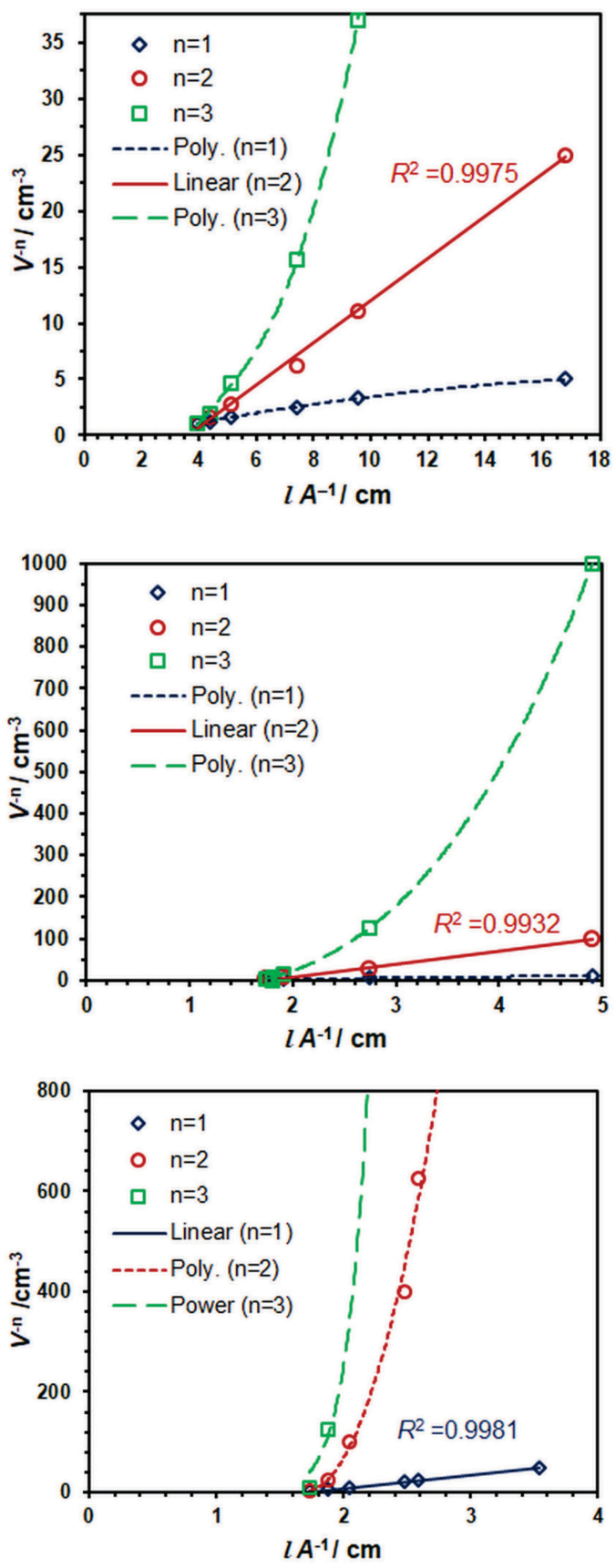

Figure 7. Determination of the HTAR-to-Ga molar ratio in the absence (a) and presence (b) of XMH and the XMH-toGa molar ratio (c) by the straight-line method of Asmus. The experimental conditions are given in Figsures 4 and 5, respectively. 
Table 2. Extraction characteristics.

\begin{tabular}{|c|c|c|c|}
\hline \multirow{2}{*}{ Extraction characteristic } & \multicolumn{3}{|c|}{ Extraction system } \\
\hline & Ga-HTAR-XMH & Ga-TAR-XMH ${ }^{[22]}$ & Ga-PAR-XMH ${ }^{[22]}$ \\
\hline \multirow{2}{*}{ Extraction constant $\left(\log K_{\mathrm{ex}}\right)$} & $4.40 \pm 0.10(N=5)^{(a)}$ & $3.80 \pm 0.20(N=5)^{(\mathrm{a})}$ & $4.10 \pm 0.10(N=5)^{(a)}$ \\
\hline & $4.44 \pm 0.03(N=5)^{(b)}$ & $3.80 \pm 0.10(N=5)^{(b)}$ & $4.10 \pm 0.04(N=5)^{(b)}$ \\
\hline Distribution ratio $(\log D)$ & $2.2 \pm 0.2(N=3)$ & $1.5 \pm 0.2(N=4)$ & $1.5 \pm 0.3(N=3)$ \\
\hline Fraction extracted $(E), \%$ & $99.3 \pm 0.3(N=3)$ & $97 \pm 1(N=4)$ & $97 \pm 1(N=3)$ \\
\hline
\end{tabular}

(a) Molar equilibrium method.
(b) Holme-Langmyhr method.

method. ${ }^{[39]}$ The obtained values are given in Table 2, along with the values for fraction extracted $(E)$ and distribution ratio $(D)$. For comparison, in Table 2 are included data for similar systems involving XMH and other azo dyes: 4-(2-

Table 3. Effect of foreign ions in determination of $7.0 \mu \mathrm{g}$ of $\mathrm{Ga}(I I I)$.

\begin{tabular}{|c|c|c|c|c|}
\hline \multirow{2}{*}{$\begin{array}{l}\text { Foreign } \\
\text { ion (FI) } \\
\text { added }\end{array}$} & \multirow{2}{*}{ Added salt } & \multirow{2}{*}{$\begin{array}{c}\mathrm{FI}: \mathrm{Ga}(\mathrm{III}) \\
\text { mass } \\
\text { ratio }\end{array}$} & \multicolumn{2}{|c|}{$\begin{array}{c}\text { Amount of } \mathrm{Ga}(\mathrm{III}) \\
\text { found }\end{array}$} \\
\hline & & & $\mu \mathrm{g}$ & $\%$ \\
\hline $\mathrm{Al}(\mathrm{III})$ & $\mathrm{Al}_{2}\left(\mathrm{SO}_{4}\right)_{3} \cdot 18 \mathrm{H}_{2} \mathrm{O}$ & 1 & 6.78 & 97.2 \\
\hline $\mathrm{Ba}(\mathrm{II})$ & $\mathrm{Ba}\left(\mathrm{NO}_{3}\right)_{2}$ & 2000 & 6.86 & 98.3 \\
\hline $\mathrm{Bi}(\mathrm{III})$ & $\mathrm{Bi}\left(\mathrm{NO}_{3}\right)_{3} \cdot 5 \mathrm{H}_{2} \mathrm{O}$ & 200 & 6.93 & 99.4 \\
\hline $\mathrm{Ca}(\mathrm{II})$ & $\mathrm{Ca}\left(\mathrm{NO}_{3}\right)_{2} \cdot 4 \mathrm{H}_{2} \mathrm{O}$ & 2000 & 7.07 & 101 \\
\hline $\mathrm{Cd}(\mathrm{II})$ & $\mathrm{CdCl}_{2}$ & 1 & 7.23 & 104 \\
\hline $\mathrm{Co}(\mathrm{II})$ & $\mathrm{CoSO}_{4} \cdot 7 \mathrm{H}_{2} \mathrm{O}$ & 0.1 & 7.16 & 103 \\
\hline $\mathrm{Cr}(I I I)$ & $\mathrm{Cr}_{2}\left(\mathrm{SO}_{4}\right)_{3}$ & 1 & 6.76 & 96.9 \\
\hline $\mathrm{Cr}(\mathrm{VI})$ & $\mathrm{K}_{2} \mathrm{CrO}_{4}$ & 0.5 & 6.97 & 100 \\
\hline $\mathrm{Cu}(\mathrm{II})$ & $\mathrm{CuSO}_{4} \cdot 5 \mathrm{H}_{2} \mathrm{O}$ & 0.1 & 7.07 & 101 \\
\hline F- & $\mathrm{NaF}$ & 50 & 6.78 & 97.2 \\
\hline $\mathrm{Fe}(\mathrm{III})$ & $\mathrm{NH}_{4} \mathrm{Fe}\left(\mathrm{SO}_{4}\right)_{2} \cdot 12 \mathrm{H}_{2} \mathrm{O}$ & 0.1 & 7.16 & 103 \\
\hline $\mathrm{Hg}(I I)$ & $\mathrm{Hg}\left(\mathrm{NO}_{3}\right)_{2} \cdot \mathrm{H}_{2} \mathrm{O}$ & 10 & 7.14 & 102 \\
\hline $1-$ & $\mathrm{KI}$ & 2000 & 7.00 & 100 \\
\hline$K(I)$ & $\mathrm{K}_{2} \mathrm{SO}_{4}$ & 2000 & 7.00 & 100 \\
\hline $\operatorname{Li}(I)$ & $\mathrm{Li}_{2} \mathrm{SO}_{4} \cdot \mathrm{H}_{2} \mathrm{O}$ & 2000 & 7.14 & 102 \\
\hline $\mathrm{Mg}(\mathrm{II})$ & $\mathrm{Mg}\left(\mathrm{NO}_{3}\right)_{2} \cdot 6 \mathrm{H}_{2} \mathrm{O}$ & 2000 & 6.72 & 96.4 \\
\hline $\mathrm{Mn}(I I)$ & $\mathrm{MnSO}_{4} \cdot \mathrm{H}_{2} \mathrm{O}$ & 5 & 7.14 & 102 \\
\hline $\mathrm{Mo}(\mathrm{VI})$ & $\left(\mathrm{NH}_{4}\right)_{6} \mathrm{Mo}_{7} \mathrm{O}_{24} \cdot 4 \mathrm{H}_{2} \mathrm{O}$ & 50 & 7.16 & 103 \\
\hline $\mathrm{Ni}(I I)$ & $\mathrm{NiSO}_{4} \cdot 7 \mathrm{H}_{2} \mathrm{O}$ & 0.1 & 7.01 & 100.6 \\
\hline NO3- & $\mathrm{NH}_{4} \mathrm{NO}_{3}$ & 2000 & 7.07 & 101 \\
\hline $\mathrm{Pb}(I I)$ & $\mathrm{Pb}\left(\mathrm{NO}_{3}\right)_{2}$ & 10 & 7.18 & 103 \\
\hline ReVII & $\mathrm{NH}_{4} \mathrm{ReO}_{4}$ & 2000 & 6.76 & 96.9 \\
\hline$V(V)$ & $\mathrm{NH}_{4} \mathrm{VO}_{3}$ & 0.1 & 6.97 & 100 \\
\hline $\mathrm{W}(\mathrm{VI})$ & $\mathrm{Na}_{2} \mathrm{WO}_{4} \cdot 2 \mathrm{H}_{2} \mathrm{O}$ & 25 & 6.81 & 97.7 \\
\hline $\mathrm{Zn}(I I)$ & $\mathrm{ZnSO}_{4} \cdot 7 \mathrm{HyO}$ & 7.5 & 6.91 & 99.0 \\
\hline
\end{tabular}

thiazolylazo)resorcinol (TAR) and 4-(2-pirydylazo)resorcinol (PAR). Obviously, HTAR has better extraction ability than TAR and PAR. This can be attributed to its higher hydrophobicity.

\section{Beer's Law and Analytical Characteristics}

The relationship between concentration of $\mathrm{Ga}(\mathrm{III})_{(\mathrm{aq})}$ and absorbance of the extract was studied under the optimal conditions (Table 1$)$. A good linearity was obtained in the range of $0.06-0.84 \mu \mathrm{g} \mathrm{cm}^{-3}\left(R^{2}=0.9992, N=6\right)$. The linear regression equation was $A=0.833 \gamma+0.0003$, where $A$ is the absorbance and $\gamma$ is the $\mathrm{Ga}$ (III) concentration $\left(\mu \mathrm{g} \mathrm{cm}^{-3}\right)$. The standard deviations of the slope and intercept were 0.011 and 0.005 , respectively. The limits of detection (LOD) and quantitation (LOQ) were calculated in two ways: 3 - and 10-times standard deviation of the intercept divided by the slope and 3- and 10-times standard deviation of the blank divided by the slope. The obtained values practically coincided: $L O D=18 \mathrm{ng} \mathrm{cm}^{-3}$ and $\mathrm{LOQ}=60 \mathrm{ng} \mathrm{cm}^{-3}$. The molar absorptivity $(\varepsilon)$ and Sandell's sensitivity $(S)$ at $\lambda_{\max }=521 \mathrm{~nm}$ were calculated as well: $\varepsilon=5.8 \times 10^{4} \mathrm{dm}^{3} \mathrm{~mol}^{-1} \mathrm{~cm}^{-1}$ and $S=1.2 \times 10^{-3} \mu \mathrm{g} \mathrm{cm}^{-2}$.

\section{Effect of Foreign Ions}

The effect of foreign ions is summarized in Table 3. The most significant interferences were caused by $\mathrm{Co}(\mathrm{II}), \mathrm{Cu}(\mathrm{II})$, $\mathrm{Fe}(\mathrm{III}), \mathrm{Ni}(\mathrm{II})$ and $\mathrm{V}(\mathrm{V})$ which form intensively colored extractable species with HTAR under the specified working conditions.

\section{CONCLUSIONS}

The present work shed light on the complex formation between Ga(III) and HTAR in the presence or absence of XMH. The conditions of formation of two electroneutral complexes, were found: $[\mathrm{Ga}(\mathrm{HL}) \mathrm{L})]$ and $\left(\mathrm{XMH}^{+}\right)\left[\mathrm{GaL}_{2}\right]$. The first one contains one monoprotonated and one deprotonated HTAR. It is extracted at a maximum extent at $\mathrm{pH}$ 6.4. The extraction characteristics are better in the presence of $\mathrm{XMH}$ and the molar absorptivity is higher. Under the optimal working conditions $\left(\mathrm{pH}=5.0, c_{\mathrm{HTAR}}=1.4 \times 10^{-4} \mathrm{~mol} \mathrm{dm}^{-3}\right.$, 
$\left.C_{X M H}=1.0 \times 10^{-3} \mathrm{~mol} \mathrm{dm}^{-3}, t_{\mathrm{ex}}=3 \mathrm{~min}\right), \mathrm{Ga}^{\mathrm{III}}$ is extracted quantitatively. The obtained values of $K_{\mathrm{ex}}, D$ and $E \%$ are higher in comparison to those achieved with similar azo dyes.

\section{REFERENCES}

[1] M. Frenzel, The distribution of gallium, germanium and indium in conventional and non-conventional resources - implications for global availability, PhD thesis, Freiberg University of Mining and Technology, 2016.

[2] R. R. Moskalyk, Miner. Eng. 2003, 16, 921-929. https://doi.org/10.1016/j.mineng.2003.08.003

[3] U. S. Suryavanshi, S. R. Shukla, Ind. Eng. Chem. Res. 2009, 48, 870-876.

https://doi.org/10.1021/ie801259c

[4] J. Huang, Y. Wang, G. Zhou, Y. Gu,. Int. J. Coal Prep. Util. 2020.

https://doi.org/10.1080/19392699.2020.1755662

[5] F. Lu, T. Xiao, J. Lin, Z. Ning, Q. Long, L. Xiao, F. Huang, W. Wang, Q. Xiao, X. Lan, H. Chen, Hydrometallurgy 2017, 174, 105-115.

https://doi.org/10.1016/j.hydromet.2017.10.010

[6] M. Frenzel, C. Mikolajczak, M. A. Reuter, J. Gutzmer, Resour. Policy 2017, 52, 327-335.

https://doi.org/10.1016/j.resourpol.2017.04.008

[7] G. R. Anpilogova, S. O. Bondareva, Y. I. Murinov, Russ. J. Gener. Chem. 2018, 88, 1478-1483. https://doi.org/10.1134/S1070363218070204

[8] T. Cui, X. Zhu, L. Wu, X. Tan, Microchem. J. 2020, 157, 104993.

https://doi.org/10.1016/j.microc.2020.104993

[9] A. S. Amin, S. M. N. Moalla, RSC Adv. 2016, 6, 19381944. https://doi.org/10.1039/C5RA21368A

[10] P. Shao, W. Wang, L. Chen, P. Duan, F. Qian, M. Ma, W. Xiong, S. Yu, J. Geochem. Explor. 2018, 185, 116119. https://doi.org/10.1016/j.gexplo.2017.11.010

[11] A. Kandil, T. Lasheen, N. Abd El-Atty, W. El-Naggar, W. Hafez, Arab J. Nucl. Sci. Appl. 2014, 47, 68.

[12] S. Nayak, N. Devi, Hydrometallurgy 2017, 171, 191197.

https://doi.org/10.1016/j.hydromet.2017.04.016

[13] M. Langova-Hnilickova, L. Sommer, Talanta 1969, 16, 681-690. https://doi.org/10.1016/0039-9140(69)80098-6

[14] M. A. Karve, S. M. Khopkar, Chem. Anal. (Warsaw) 1993, 38, 469-476.

[15] U. Divrikli, M. Soylak, L. Elci, Anal. Lett. 2003, 36, 839-852. https://doi.org/10.1081/AL-120018803

[16] T. Biver, A. Boggioni, F. Secco, M. Venturini, Langmuir 2008, 24, 36-42. https://doi.org/10.1021/la7024796
[17] Y. S. Thakare, D. D. Malkhede, Sep. Sci. Technol. 2014, 49, 1198-1207. https://doi.org/10.1080/01496395.2013.872657

[18] Y. Chen, Y. Deng, Y. Meng, S. Zhang, J. Chem. Eng. Data 2015, 60, 1464-1468.

https://doi.org/10.1021/acs.jced.5b00010

[19] K. T. Stojnova, K. B. Gavazov, G. K. Toncheva, V. D. Lekova, A. N. Dimitrov, Cent. Eur. J. Chem. 2012, 10, 1262-1270. https://doi.org/10.2478/s11532-012-0045-y

[20] K. T. Stojnova, K. B. Gavazov, V. D. Lekova, Acta Chim. Slov. 2013, 60, 390-396.

[21] P. V. Racheva, K. T. Stojnova, V. D. Lekova, A. N. Dimitrov, Croat. Chem. Acta 2015, 88, 159-163. https://doi.org/10.5562/cca2434

[22] P. V. Racheva, D. G. Hristov, K. B. Gavazov, Russ. J. Gener. Chem. 2020, 90, 1351-1356. https://doi.org/10.1134/S1070363220070245

[23] D. Hristov, N. Milcheva, K. Gavazov, Acta Chim. Slov. 2019, 66, 987-994. https://doi.org/10.17344/acsi.2019.5244

[24] S. Ghose, J. Dattagupta, Acta Crystallog. C 1986, 42, 1524-1526.

https://doi.org/10.1107/S0108270186091618

[25] Y. Anjaneyulu, M. R. Reddy, C. S. Kavipurapu, Analyst 1986, 111, 1167-1169. https://doi.org/10.1039/an9861101167

[26] C. S. Kavipurapu, S. C. Srivastava, K. K. Gupta, L. P. Pandey, Mikrochim. Acta 1993, 111, 127-132. https://doi.org/10.1007/BF01240175

[27] S. Khalil, Microchim. Acta 1999, 130, 181-184. https://doi.org/10.1007/BF01244925

[28] K. B. Gavazov, T. S. Stefanova, Croat. Chem. Acta 2014, 87, 233-240. https://doi.org/10.5562/cca2436

[29] S. A. Wood, I. M. Samson, Ore Geol. Rev. 2006, 28, 57-102. https://doi.org/10.1016/j.oregeorev.2003.06.002

[30] A. Hulanicki, S. Glab, G. Ackermann, Pure Appl. Chem. 1983, 55, 1137-1230.

https://doi.org/10.1351/pac198355071137

[31] K. Pytlakowska, V. Kozik, M. Dabioch, Talanta 2013, 110, 202-228.

https://doi.org/10.1016/j.talanta.2013.02.037

[32] D. G. Hristov, P. V. Racheva, G. K. Toncheva, K. B. Gavazov, Acta Chim. Slov. 2021. http://dx.doi.org/10.17344/acsi.2020.6035

[33] N. Menek, E. Eren, S. Topçu, Dyes Pigm. 2006, 68, 205-210.

https://doi.org/10.1016/j.dyepig.2005.01.010

[34] K. B. Gavazov, G. K. Toncheva, Russ. J. Gener. Chem. 2015, 85, 192-197. https://doi.org/10.1134/\$1070363215010338 
[35] L. Marić, M. Široki, Anal. Chim. Acta 1996, 318, 345355. https://doi.org/10.1016/0003-2670(95)00444-0

[36] Z. Zhiming, M. Dongsten, Y. Cunxiao, J. Rare Earths 1997, 15, 216-219.

[37] E. Asmus, Fresenius' J. Anal. Chem. 1960, 178, 104116. https://doi.org/10.1007/BF00467200
[38] K. Mochizuki,; T. Imamura,; T. Ito, M. Fujimoto, Bull. Chem. Soc. Jpn. 1978, 51, 1743-1750. https://doi.org/10.1246/bcsj.51.1743

[39] A. Holme, F. J. Langmyhr, Anal. Chim. Acta 1966, 36, 383-391.

https://doi.org/10.1016/0003-2670(66)80066-1 